\title{
Effects of Kinesio taping on blood fatigue factors after isokinetic exercise
}

\author{
Young Jun Ko' ${ }^{1}$, Jun-Su Kim ${ }^{2 * *}$ \\ ${ }^{1}$ Major in Sport Service Practice, College of Welfare Convergence, Kangnam University, Yongin, Korea \\ ${ }^{2}$ Department of Sports and Outdoors, College of Bio Convergence, Eulji University, Seongnam, Korea
}

This study examined the effects of Kinesio taping on recovery from fatigue induced by an exercise of concentric contraction using an isokinetic machine. Eight healthy collegiate students participated in two experiments: the Kinesio taping application condition and the no Kinesio taping application condition. The fatigue was induced by concentric exercise at $60 \%$ sec, 50 repetitions for one session, and repeated 3 sessions. Changes of blood ammonia, lactate, lactate dehydrogenase (LDH), and creatinine kinase (CK) were monitored. Blood was collected before exercise, immediately after exercise, $24 \mathrm{hr}$ after exercise, and $72 \mathrm{hr}$ after exercise. Blood ammonia tended to reduce during the recovery pro- cess, but no differences were found between conditions. Blood lactate tended to reduce during the recovery process, but no differences were found between conditions. In the blood LDH, no differences were found between conditions. Blood creatine kinase tended to reduce during the recovery process, but no differences were found between conditions. The present results showed that Kinesio taping did not affect the recovery phase of blood ammonia, lactate concentration, LDH, and CK.

Keywords: Kinesio taping, Ammonia, Lactate, Lactate dehydrogenase, Creatine kinase

\section{INTRODUCTION}

Fatigue can be defined as an increase in the concentration of metabolic by-products due to prolonged exercise or continuous stimulation, or a decrease in the body's response or ability to function due to depletion of the energy supply (Armstrong, 1990). Longterm muscle exercise causes waste products by chemical changes in the muscle, and when glycolysis and adenosine triphosphate are depleted, the contraction of muscle fibers decreases, leading to fatigue.

Ammonia is biosynthesized through normal amino acid metabolism and is toxic at high concentrations. The immediate source of ammonia in the muscle appears to be the result of deamination of adenosine monophosphate and is more evident in fast twitch than slow twitch fibers (Mutch and Banister, 1983). The liver converts ammonia into urea through a series of reactions known as the urea cycle. Liver dysfunction, such as those seen with cirrhosis, can lead to hyperammonemia. Hyperammonemia causes confusion and coma in hepatic encephalopathy, as well as neurological disorders common in people with urea cycle defects and organic aciduria.

During power exercises such as sprinting, high energy demand causes glucose to break down and oxidize to pyruvate, and lactic acid is produced from pyruvate faster than the body can process, resulting in a rise in lactic acid concentration. Glucose is generally considered the main source of energy for living tissue, but there are indications that it is lactic acid and not glucose. It is preferentially metabolized by neurons in the brain of several mammalian species, such as mice, rats, and humans (Wyss et al., 2011; Zilberter et al., 2010).

Lactate dehydrogenase (LDH) catalyzes the conversion of lactic acid to pyruvate. The onset of acidosis during periods of vigorous exercise is usually due to the accumulation of hydrogen separated from lactic acid. Previously, lactic acid was thought to cause fatigue. LDH activity correlates with muscle fatigue (Tesch et al., 1978), but lactate production by the LDH complex acts as a sys-
${ }^{*}$ Corresponding author: Jun-Su Kim (1D https://orcid.org/0000-0002-7078-4926 Department of Sports and Outdoors, College of Bio Convergence, Eulji University, 553 Sanseong-daero, Sujeong-gu, Seongnam 13135, Korea Email: kjskjs777@hanmail.net

Received: February 12, 2021 / Accepted: March 14, 2021
This is an Open Access article distributed under the terms of the Creative Commons Attribution Non-Commercial License (https://creativecommons.org/licenses/by-nc/4.0/) which permits unrestricted non-commercial use, distribution, and reproduction in any medium, provided the original work is properly cited. 
tem that delays the onset of muscle fatigue.

Exercise increases the outflow of creatine kinase to the blood stream for up to a week, and this is the most common cause of high creatinine kinase (CK) in blood (Johnsen et al., 2011). High $\mathrm{CK}$ in the blood can indicate damage to tissues rich in $\mathrm{CK}$, such as rhabdomyolysis, myocardial infarction, myositis, and myocarditis. CK in blood may be elevated in the use of medication such as statins, endocrine disorders such as hypothyroidism, and skeletal muscle diseases and disorders including malignant hyperthermia.

Kinesio taping is an elastic taping by attaching tape to the muscle area to normalize the function of the main muscle. Kinesio taping therapy applies adhesive tape to the muscle itself and uses the principle of muscle constancy to improve muscle spasms, tension, circulation of blood, tissues, and lymph fluid. This study investigated the effect of Kinesio taping on fatigue-inducing factors due to concentric contractile motion using an isokinetic machine.

\section{MATERIALS AND METHODS}

\section{Participants}

Eight men from the Department of Physical Education of Eulji University were selected for this study. Only those who were healthy without specific diseases, fully understood the purpose and procedure of the experiment, and voluntarily expressed their intention to participate in the experiment participated in the experiment. This experiment was approved by the Research Ethics Committee of Eulji University (EU-2020-235). The characteristics of the participants are shown in Table 1.

\section{Experiment procedure}

In order to exclude fatigue factors, the overall contents and precautions before the experiment were sufficiently explained to refrain from drinking alcohol or excessive exercise for 2 days before the experiment. Using a body composition analyzer, the body com-

Table 1. Physical traits of participant $(n=8)$

\begin{tabular}{lc}
\hline Variable & Value \\
\hline Age $(\mathrm{yr})$ & $21.60 \pm 1.60$ \\
Height $(\mathrm{cm})$ & $174.10 \pm 6.92$ \\
Weight $(\mathrm{kg})$ & $70.89 \pm 14.00$ \\
Body mass index $\left(\mathrm{kg} / \mathrm{m}^{2}\right)$ & $21.33 \pm 1.69$ \\
Skeletal muscle $(\mathrm{kg})$ & $33.00 \pm 5.90$ \\
Fat $(\mathrm{kg})$ & $57.89 \pm 8.72$
\end{tabular}

Values are presented as mean \pm standard deviation. position of eight subjects was measured $2 \mathrm{hr}$ before the test, and blood was collected in a stable state. This experiment was performed twice, and in the first test, subjects were divided into two groups: $\mathrm{n}=4$ in the Kinesio applied group and $\mathrm{n}=4$ in the Kinesio nonapplied group. Two weeks later, second test was conducted in the same way as the first test.

This experiment was designed to exert maximum force during stretching as well as during flexion using the isokinetic device (Cybex 770, Cybex International, Inc., Ronkonkoma, NY, USA). Prior to the experiment, participants practiced 5 times to adapt to the isokinetic device, and the experiment proceeded until the subject could no longer exert their power. Isokinetic shortening contractions were performed, at $60^{\circ} \mathrm{sec}, 50$ times each round, for 3 rounds, followed by 10 sec breaks every 50 times.

\section{Blood collection}

After performing muscle contraction using an isokinetic device, $20 \mathrm{~mL}$ of blood was drawn from arterial blood in the subject's forearm. Immediately, plasma was separated and analyzed for ammonia, lactic acid, LDH, and CK. Blood sampling was performed immediately after exercise, $24 \mathrm{hr}$ after exercise, and $72 \mathrm{hr}$ after exercise.

\section{Application of Kinesio taping}

In the state of extending the muscle position as much as possible, tape was attached without stretching, and I-shaped and Y-shaped tapes were attached to the origin and insertion site of the muscle.

\section{Taping on quadriceps muscle}

Subject lied down, bended knees, fixed the tape on the anterior iliac spine, attached the tape to the front of the rectus femoris, and wrapped the patella in a Y-shape.

\section{Taping on hamstring}

In a prone position, the subject started at the upper part of the sciatic nodule, attaches the tape to the third of the lower thigh, and then attached it in half lengthwise, one toward the fibula head toward the outside, and the other toward the lower part of the inner tibia.

\section{Taping on vastus medialis}

Subject applied tape to the origin of the adductor muscle while lying on the bed with the tip of the toe stretched out, the leg was stretched and the tape was taken over the vastus medialis insertion, bent the knee, and then affixed under the patella. 


\section{Taping on vastus lateralis}

The subject was lying on the bed, taped to the origin of the speculum muscle, inserted the parietal muscle, and bent the knee and attached it under the patella.

\section{Data processing}

Data processing was performed using the SPSS ver. 12.0 (SPSS Inc., Chicago, IL, USA), and the mean value and standard deviation of each variable were calculated. Two-way analysis of variance with repeated measurements was performed to determine differences in fatigue recovery blood parameters due to application of Kinesio taping and timing (before exercise, immediately after exercise, $24 \mathrm{hr}$ after recovery, $72 \mathrm{hr}$ after recovery). The significance level of all tests was set to $P<0.05$.

\section{RESULTS}

\section{Changes in ammonia in the blood}

In Table 2, the changes in ammonia in the blood of applied group and nonapplied group showed no statistically significant difference in the interaction between timing and group $(P>$ $0.05)$. Examining by main effect, in the taping applied group, it is shown $162.62 \pm 65.64(\mu \mathrm{g} / \mathrm{dL})$ before exercise, $292.37 \pm$ $104.36(\mu \mathrm{g} / \mathrm{dL})$ immediately after exercise, $208.37 \pm 57.83(\mu \mathrm{g} / \mathrm{dL})$ $24 \mathrm{hr}$ of recovery, $205.87 \pm 51.6(\mu \mathrm{g} / \mathrm{dL}) 72 \mathrm{hr}$ of recovery. In the nonapplied group, it is appeared $166.12 \pm 94.96(\mu \mathrm{g} / \mathrm{dL})$ before exercise, $263.37 \pm 97.81(\mu \mathrm{g} / \mathrm{dL})$ immediately after exercise, $201.25 \pm 58.47(\mu \mathrm{g} / \mathrm{dL}) 24 \mathrm{hr}$ of recovery, and $206.87 \pm 73.68$ $(\mu \mathrm{g} / \mathrm{dL}) 72 \mathrm{hr}$ of recovery, showing a statistically major difference. There were no statistically significant differences between the two groups $(P>0.05)$

\section{Changes in lactic acid concentration}

In Table 2, the changes in lactic acid concentration of the applied group and nonapplied group showed no statistically significant difference in interaction between the timing and the group. Examining by main effect, in the taping applied group, it is shown $1.23 \pm 0.28(\mathrm{mmol} / \mathrm{L})$ before exercise, $9.07 \pm 2.25(\mathrm{mmol} / \mathrm{L}) \mathrm{im}-$ mediately after exercise, $1.44 \pm 0.37(\mathrm{mmol} / \mathrm{L}) 24 \mathrm{hr}$ of recovery, and $1.08 \pm 0.27(\mathrm{mmol} / \mathrm{L}) 72 \mathrm{hr}$ of recovery. In the nonapplied group, it is appeared $1.27 \pm 0.40(\mathrm{mmol} / \mathrm{L})$ before exercise, $9.05 \pm$ $2.27(\mathrm{mmol} / \mathrm{L})$ immediately after exercise, $1.56 \pm 0.59(\mathrm{mmol} / \mathrm{L})$ $24 \mathrm{hr}$ of recovery, and $1.50 \pm 0.53(\mathrm{mmol} / \mathrm{L}) 72 \mathrm{hr}$ of recovery, showing a statistically major difference. There were no statistically significant differences between the two groups $(P>0.05)$.

\section{Changes in LDH}

In Table 2, the changes in LDH of the applied group and nonapplied group showed no statistically significant difference in interaction between the timing and the group. Examining by main effect, in the taping applied group, it is shown $290.37 \pm 58.14$ (U/L) before exercise, 287.12 \pm 59.81 (U/L) immediately after exercise, $287.50 \pm 46.77$ (U/L) $24 \mathrm{hr}$ of recovery, and 291.50 \pm 62.52 (U/L) $72 \mathrm{hr}$ of recovery. In the nonapplied group, it is appeared $330.12 \pm 163.23$ (U/L) before exercise, 301.12 \pm 60.34 (U/L) immediately after exercise, $293.00 \pm 37.06$ (U/L) $24 \mathrm{hr}$ of recovery, and $272.62 \pm 42.16(\mathrm{U} / \mathrm{L}) 72 \mathrm{hr}$ of recovery, showing no significant difference. There were no statistically substantial differences between the two groups $(P>0.05)$.

Table 2. Changes of blood variations associated with fatigue recover

\begin{tabular}{|c|c|c|c|c|c|c|c|c|}
\hline Variable & Group & Before exercise & $\begin{array}{c}\text { Immediately after } \\
\text { exercise }\end{array}$ & $\begin{array}{l}24 \mathrm{Hr} \text { after } \\
\text { recovery }\end{array}$ & $\begin{array}{l}72 \mathrm{Hr} \text { after } \\
\text { recovery }\end{array}$ & Source & $F$ & $P$-value \\
\hline Ammonia ( $\mu \mathrm{g} / \mathrm{dL})$ & $\begin{array}{l}\text { Applied } \\
\text { Nonapplied }\end{array}$ & $\begin{array}{l}162.62 \pm 65.64 \\
166.12 \pm 94.96\end{array}$ & $\begin{array}{l}292.37 \pm 104.36 \\
263.37 \pm 97.81\end{array}$ & $\begin{array}{l}208.37 \pm 57.83 \\
201.25 \pm 58.47\end{array}$ & $\begin{array}{l}205.87 \pm 51.60 \\
206.87 \pm 73.68\end{array}$ & $\begin{array}{l}\text { Timing } \\
\text { Group } \\
\text { Interaction of timing } \times \text { group }\end{array}$ & $\begin{array}{r}33.880 \\
0.048 \\
0.434\end{array}$ & $\begin{array}{l}0.000^{* * *} \\
0.830 \\
0.733\end{array}$ \\
\hline Lactic acid (mmol/L) & $\begin{array}{l}\text { Applied } \\
\text { Nonapplied }\end{array}$ & $\begin{array}{l}1.23 \pm 0.28 \\
1.27 \pm 0.40\end{array}$ & $\begin{array}{l}9.07 \pm 2.25 \\
9.05 \pm 2.27\end{array}$ & $\begin{array}{l}1.44 \pm 0.37 \\
1.56 \pm 0.59\end{array}$ & $\begin{array}{l}1.08 \pm 0.27 \\
1.50 \pm 0.53\end{array}$ & $\begin{array}{l}\text { Timing } \\
\text { Group } \\
\text { Interaction of timing } \times \text { group }\end{array}$ & $\begin{array}{r}83.320 \\
0.163 \\
1.006\end{array}$ & $\begin{array}{l}0.000^{* * *} \\
0.693 \\
0.424\end{array}$ \\
\hline $\begin{array}{l}\text { Lactate dehydrogenase } \\
\text { (U/L) }\end{array}$ & $\begin{array}{l}\text { Applied } \\
\text { Nonapplied }\end{array}$ & $\begin{array}{l}290.37 \pm 58.14 \\
330.12 \pm 163.23\end{array}$ & $\begin{array}{l}287.12 \pm 59.81 \\
301.12 \pm 60.34\end{array}$ & $\begin{array}{l}287.50 \pm 46.77 \\
293.00 \pm 37.06\end{array}$ & $\begin{array}{l}291.50 \pm 62.52 \\
272.62 \pm 42.16\end{array}$ & $\begin{array}{l}\text { Timing } \\
\text { Group } \\
\text { Interaction of timing } \times \text { group }\end{array}$ & $\begin{array}{l}0.454 \\
0.124 \\
0.801\end{array}$ & $\begin{array}{l}0.719 \\
0.730 \\
0.517\end{array}$ \\
\hline Creatine kinase (U/L) & $\begin{array}{l}\text { Applied } \\
\text { Nonapplied }\end{array}$ & $\begin{array}{l}124.12 \pm 65.94 \\
180.75 \pm 141.74\end{array}$ & $\begin{array}{l}139.37 \pm 73.41 \\
192.62 \pm 161.20\end{array}$ & $\begin{array}{l}231.87 \pm 98.64 \\
257.75 \pm 117.75\end{array}$ & $\begin{array}{l}146.50 \pm 80.80 \\
144.75 \pm 86.56\end{array}$ & $\begin{array}{l}\text { Timing } \\
\text { Group } \\
\text { Interaction of timing } \times \text { group }\end{array}$ & $\begin{array}{r}12.278 \\
0.570 \\
0.406\end{array}$ & $\begin{array}{l}0.001^{* *} \\
0.463 \\
0.752\end{array}$ \\
\hline
\end{tabular}

${ }^{* *} P<0.001 .{ }^{* * *} P<0.001$. 


\section{Changes in CK}

In Table 2, the changes in CK of the applied group and nonapplied group showed no statistically significant difference in interaction between the timing and the group. Observing by the main effect, in the taping applied group, it is shown 124.12 \pm 65.94 (U/L) before exercise, $139.37 \pm 73.41$ (U/L) immediately after exercise, $281.87 \pm 98.64$ (U/L) $24 \mathrm{hr}$ of recovery, and $146.50 \pm 80.80$ $(\mathrm{U} / \mathrm{L}) 72 \mathrm{hr}$ of recovery. In the nonapplied group, it is appeared $180.75 \pm 141.74$ (U/L) before exercise, $192.62 \pm 161.20$ (U/L) immediately after exercise, $257.75 \pm 117.75$ (U/L) $24 \mathrm{hr}$ of recovery, and $144.75 \pm 86.56$ (U/L) $72 \mathrm{hr}$ of recovery, showing a statistically major difference. There were no statistically significant differences between the two groups $(P>0.05)$.

\section{DISCUSSION}

The three types of pain associated with exercise are pain experienced during or immediately after exercise, delayed muscle pain, and pain due to muscle spasm (Miles and Clarkson, 1994). Muscle fatigue due to eccentric muscle contraction activity is associated with a high load ratio of muscle tissue (Enoka, 1996). Muscle fatigue reduced the range of motion in the joint and increased muscle extension, circumference, and volume (Friden et al., 1998). Strength and core endurance are factors that contribute to athlete performance and the prevalence of injuries (Kocahan and Akınoğlu, 2018). The complex movements of an athlete can cause many injuries to the athlete's lower limbs (Park et al., 2020). Eccentric contractions cause more fatigue than contraction contractions. Kinesio taping can be considered a useful method for decreasing pain without any side effects in patients with osteoarthritis (Abolhasani et al., 2019). Applying horseshoe taping to the upper and lower patellar with kinesiology tape is more helpful in immediate recovery after exercise-induced quadriceps fatigue (Son et al., 2020).

Increases in blood ammonia levels have been reported in rats after swimming and in humans after arm movements, maximal cycle ergometers, and treadmill exercise (Mutch and Banister, 1983). In this study, blood ammonia after causing muscle fatigue with/ without taping showed no statistically significant difference in the interaction of timing and group between the applied and nonapplied group $(P>0.05)$. There was a significant difference among the timings in the group $(P<0.05)$, and there was no significant difference in the concentration of blood ammonia between groups $(P>0.05)$

Lactic acid is important in the early stages of development for brain metabolism in prenatal and early postpartum subjects, and lactic acid at these stages has a higher concentration in body fluids and is used in the brain preferentially over glucose (Zilberter et al., 2010). In this study, blood lactic acid concentration after inducing muscle fatigue with/without taping showed no statistically significant difference in the interaction between the timing and group $(P>0.05)$. There was a significant difference among the timings in the group $(P<0.05)$, and there was no significant difference in the concentration of lactic acid between groups $(P>0.05)$.

Because LDH is released during tissue damage, it is an indicator of common injuries and diseases such as heart failure. LDH prevents muscle failure and fatigue in several ways. Muscular acidosis occurs when proton accumultion exceeds the absorption rate in lactic acid production and removal through the LDH symport (Juel et al., 2004). In this study, blood LDH after causing muscle fatigue with/without taping presented no statistically significant difference in the interaction of timing and group $(P>0.05)$. There was no significant difference among the timings in the group $(P>$ 0.05 ), and also no significant difference in the concentration of LDH between groups $(P>0.05)$.

Normal values at rest are usually between 60 and 400 IU/L, CK is found almost exclusively in muscle tissue and is the most common plasma marker of muscle damage (Ebbeling and Clarkson, 1989), and when the muscle is stabilized, the level of CK in the blood is decreased. In this study, blood CK after causing muscle fatigue with/without taping presented no statistically significant difference in the interaction of timing and group $(P>0.05)$. There was a significant difference among the timings in the group $(P<$ $0.05)$, and there was no significant difference in the concentration of $\mathrm{CK}$ between groups $(P>0.05)$.

It is judged that the application of Kinesio taping used in this study does not help in the reduction of blood ammonia, lactic acid, $\mathrm{LDH}$, and $\mathrm{CK}$, which are substances that cause fatigue.

\section{CONFLICT OF INTEREST}

No potential conflict of interest relevant to this article was reported.

\section{ACKNOWLEDGMENTS}

The authors received no financial support for this article.

\section{REFERENCES}

Abolhasani M, Halabchi F, Afsharnia E, Moradi V, Ingle L, Shariat A, 
Hakakzadeh A. Effects of kinesiotaping on knee osteoarthritis: a literature review. J Exerc Rehabil 2019;28;15:498-503.

Armstrong RB. Initial event in exercise induced muscular injury. Med Sci Sports Excer 1990;22:429-435.

Ebbeling CB, Clarkson PM. Exercise-induced muscle damage and adaptation. Sports Med 1989;7:207-234.

Enoka RM. Eccentric contraction require unique activation strategies by the nervous system. J Appl Physiol 1996;81:2339-2346.

Friden J, Seger J, Ekblom B. Sublethal muscle fiber injuries after high tension anaerobic exercise. Eur J Appl Physiol Occup Physiol 1998;57:360368.

Johnsen SH, Lilleng H, Wilsgaard T, Bekkelund SI. Creatine kinase activity and blood pressure in a normal population: the Tromsø study. J Hypertens 2011;29:36-42.

Juel C, Klarskov C, Nielsen JJ, Krustrup P, Mohr M, Bangsbo J. Effect of high-intensity intermittent training on lactate and $\mathrm{H}^{+}$release from human skeletal muscle. Am J Physiol Endocrinol Metab 2004;286:E245E251.

Kocahan T, Akınoğlu B. Determination of the relationship between core endurance and isokinetic muscle strength of elite athletes. J Exerc Rehabil 2018;14:413-418.
Miles MP, Clarkson PM. Exercise-induced muscle pain, soreness, and cramps. J Sports Med Phys Fitness 1994;34:203-216.

Mutch BJ, Banister EW. Ammonia metabolism in exercise and fatigue: a review. Med Sci Sports Exerc 1983;15:41-50.

Park JH, Rhyu HS, Rhi SY. The effects of instrument-assisted soft tissue mobilization rehabilitation exercise on range of motion, isokinetic strength, and balance in chronic ankle instability taekwondo players. J Exerc Rehabil 2020;16:516-521.

Son YJ, Lee JH, Choi IR. Immediate effect of patellar kinesiology tape application on quadriceps peak moment following muscle fatigue: a randomized controlled study. J Musculoskelet Neuronal Interact 2020; 20:549-555.

Tesch P, Sjödin B, Thorstensson A, Karlsson J. Muscle fatigue and its relation to lactate accumulation and LDH activity in man. Acta Physiol Scand 1978;103:413-420.

Wyss MT, Jolivet R, Buck A, Magistretti PJ, Weber B. In vivo evidence for lactate as a neuronal energy source. J Neurosci 2011;31:7477-7485.

Zilberter Y, Zilberter T, Bregestovski P. Neuronal activity in vitro and the in vivo reality: the role of energy homeostasis. Trends Pharmacol Sci 2010;31:394-401. 